\title{
REPORT ON THE XVIII INTERNATIONAL SCIENTIFIC AND PRACTICAL CONFERENCE “AXIOLOGY IN THE FINANCIAL LAW OF THE CENTRAL AND EASTERN EUROPEAN STATES" (19-20 SEPTEMBER 2019, GRODNO, REPUBLIC OF BELARUS)
}

On September 19-20, 2019 at the Yanka Kupala State University of Grodno (Republic of Belarus) was held the XVIII International scientific and practical conference "Axiology in the financial law of the Central and Eastern European States". The conference was organized by the International Law Department at the Faculty of Law together with the Center for Information and Research Organization on Public Finance and Tax Law in the Countries of Central and Eastern Europe. The conference was a continuation of the annual international scientific and practical conferences organized by the Center in Prague, Brno, Vilnius, Bialystok, Kosice, Voronezh, Paris, Lviv, Gyor, Omsk, Mikulov, etc.

More than 80 representatives took part in the conference from the universities in the Republic of Belarus, the Republic of Poland, the Czech Republic, Slovakia, the Russian Federation and the Republic of Kazakhstan. The first Vice-rector of the Yanka Kupala State University of Grodno O. A. Ramanau, the Vice-rector on Scientific Work of the Yanka Kupala State University of Grodno Y. Ramanouski, the Dean of the Faculty of Law of the Yanka Kupala State University of Grodno S. E. Cheburanova, the President of the Center for Information and Research Organization in Public Finance and Tax Law in the Countries of Central and Eastern Europe, the head of the Department of Public Finance and Financial Law of the University of Bialystok E. Ruśkowski, the Chairman of the Organizing Committee of the Conference, Associate Professor of the Department of International Law of the Yanka Kupala State University of Grodno L.Ya. Abramchik addressed the conference participants with a welcome speech.

During the conference were discussed the qualitative changes in identifying individual indicators of financial law problems that depend on society changes. Axiological aspects of financial and legal regulation, the role of financial law and its institutions in the mechanism of management in the countries of the Central and Eastern Europe were addressed. A number of reports were presented by the scientific community of the Central and Eastern Europe, well-known scientists and specialists in the field of public finance, finance and tax law researches. Professor, doctor of Legal Science A.N. Kostyukov (F.M. Dostoevsky State University of Omsk) in the speech "The constitutional values in the financial law" presented the analysis of the constitutional values system (people, their rights and freedoms, democracy, state unity and integrity, the subjects independence of the Russian Federation and municipalities, etc.) in their interaction with elements of financial and legal axiology, and also identified a number of problems of modern constitutional axiology in the financial and legal sphere, pointing out the imperfection of 
certain constitutional values in financial law. Professor, doctor of Legal Science, the President of the Center for Information and Research Organization on Public Finance and Tax Law in the Countries of Central and Eastern Europe, the Head of the Department of Public Finance and Financial Law of the University of Bialystok, E. Ruśkowski (the Republic of Poland) noted that financial law tends to change in the report "Constancy and variability of the constitutional values in financial law". This is due to the changes taking place in our public life, politics and economy. It is noteworthy that our ideas about individual values are changing, therefore the axiological approach is relevant in research. Thus, the Constitution of Poland since 1997 contains numerous values related to public finance. However, some values, or their constitutional guarantees, are currently in doubt. As a result of changes in political conditions and management methods, it is proposed to introduce new constitutional values in the field of public finance. Professor, doctor of Legal Science, the Head the of Department of Legal Regulation of Economy and Finances at the Institute of Public Administration and Management of the Russian Presidential Academy of National Economy and Public Administration under the President of the Russian Federation E.V. Chernikova, in her presentation "Axiological aspects of financial activity" proposed to consider the concept of "financial activity of the state and municipalities" as an axiological value in the financial and legal theory of legal regulation of socio-economic relations. Social processes and relations management through finance allows us to consider financial activity as a universal, i.e. suitable for all types of finance, way to manage the economic, political and social life of a society. Professor, doctor of Legal Science, the Dean of the Faculty of Law of the Caspian Public University S.P. Moroz (the Republic of Kazakhstan) presented a report on "Axiology in investment law of the Republic of Kazakhstan", in which she noted the relationship and interaction of public and private categories and institutions in modern legal regulation and stressed the importance of axiological approach in legal research in connection with this trend. Candidate of Law Sciences, the Head of the Financial Law Department of the Russian State University of Justice I.A. Tsindeliani in the report "Axiological aspects of the system of financial law" noted that legal axiology as a scientific direction allows us to consider the legal system of the state as a whole and its individual elements from the point of view of the value foundations separately existing in society and in each individual. Consideration of the state legal system elements through value categories makes it possible to determine the relationship and interdependence of all elements of the legal system. Professor, doctor of Law Science W. Morawski (the Nicholas Copernicus University, the Republic of Poland) in the report "Polycentric interpretation of tax law - principles of conflict resolution" stressed that legal principles, including financial law, are axiological values and direct regulators of public relations by their nature. Principles of tax law in the field of public finance play a role in preventing conflicts of private and public interests in taxation. The principles of tax law should not be identified with the norms of tax law by having regulatory properties, since they are independent legal means of regulation. Professor, doctor of Law Science, the honoured lawyer of the Russian Federation, chief researcher of the Department of Law of the Institute of State and Law of the Russian Academy of Sciences S.V. Zapolsky, interpreting tax law rules based on their mandatory regulatory properties, polycentrism is desirable, has made a report "Scientific grant as an axiological value", in which he showed the need for its legal support based on a particular example of obtaining a scientific grant. Professor, doctor of Legal Science, the Vice-Rector for Economics and Development of the University of Wroclaw W.M. Miemiec (the Republic of Poland), made a report "The sources of financing the budget deficit of local government units due to the changes in the Law on public finances", which raised topical issues of sources of financing the budget deficit of local government units in the Republic of Poland in the light of changes in the Law on public finance. The Professor stated that the changes made to this law make it possible to allocate funds unclaimed during the fiscal year from the total budget calculations of territorial self-government units, which are also a potential source of deficit financing, thus facilitating budget calculation and real control over local government finances at the reporting level. It is not possible to give a full assessment of the changes made to the Law on public finance at this stage, since they will find legal application only in the development and execution of territorial self-government units budgets for 2020 . Candidate of Law Sciences, Associate Professor, Associate Professor of the Department of Civil Law and Procedure of the Yanka Kupala State University of Grodno A.M. Vartanyan (the Republic of Belarus) in the speech "On some peculiarities of fulfilment of tax liabilities upon reorganization of a legal entity", disclosed the peculiarities of the institution of reorganization of a legal entity in the performance of tax obligations. The speaker focused on the relationship between the civil and tax legislation in regulating 
tax relations and showed the role of succession in the performance of tax obligations. Professor, doctor of Legal Science, the Head of the Department of Financial Law of the Voronezh State University M.V. Sentsova (Karaseva) in the report "The value characteristics of tax law and tax property relations" noted the value characteristics of tax law, emphasized the role of civil law in tax and legal regulation and regulation of tax-related property relations. Civil legislation and civil legal institutions that do not fully correspond to their normative content are applied to relations in the field of taxation that have a special tax-legal nature. And most often this is objectively necessary, since there are no legal norms that allow resolving the situation. In this regard, it is necessary to amend the Civil Code of the Russian Federation in terms of expanding (changing) certain protective institutions content, because the value of these institutions for resolving tax-related situations is very high. Professor, doctor of Legal Science I.V. Bit-Shabo (the Russian State University of Justice) made a presentation on "Trends in the development of legislation in the Russian Federation and Eastern European Countries in the sphere of state social extra-budgetary funds" and noted the main trends in the modernization of the legal framework for social security in the Russian Federation and Eastern European Countries. Based on the analysis of the legislation of Hungary, Bulgaria, Poland, Belarus and other Eastern European Countries, she justified the conclusion about possible changes in the legal regulation of social security in the Russian Federation, while noting possible negative consequences. Professor, doctor of Legal Sciences, Dean of the Faculty of Personnel Management and Public Administration of Public Service and Management Institute of the Russian Presidential Academy of National Economy and Public Administration under the President of the Russian Federation E.U. Kireeva in the report "The system of values in local governance and their implementation in the field of finance" pointed out that the question about the system of values in the law as a whole and its individual sectors in particular appears to be controversial, consensus on set of values and their hierarchy is not formed, however, in recent years increasingly wide range of scholars have been drawn to the subject, which indicates its relevance and importance for the Russian jurisprudence. Value approach to the system of local self-government, according to the scientist, should refract through the prism of constitutional ideals and values enshrined in the preamble of the Constitution and its first Chapter "Foundations of Constitutional Order". Professor, doctor of Law
Science, Professor of the Department of Public Finance and Financial Law at the University of Bialystok S. Presnarowicz (the Republic of Poland) in the report "A new model for conducting tax disputes in Poland" focused on the issues of changes in tax law. Currently, the Polish Parliament is working on the adoption of a new general tax law - Tax Ordinance Act. This law, which will come into force on January 1, 2021, provides a number of new legal solutions. In particular, the model for resolving tax disputes is changing, and the period for applying to higher tax authorities will increase from 14 to 30 days. Under certain conditions, the appellate body may be omitted, and a complaint against the first tax instance may be directly filed with the regional administrative court. Candidate of Law Sciences, Associate Professor, Associate Professor of State and Municipal Law Department of Dostoevsky Omsk State University, I.V. Glazunova, dedicated the report "Legal support of Treasury maintenance of the budget" to topical issues of legal support of the mechanism of Treasury maintenance of the budget. Candidate of Law Sciences, Associate Professor of the Department of Business, Competition and Financial Law of the Siberian Federal University E.S. Yefremova in her speech "Tax Optimization and Conflict of Values in the Light of Article 54.1 of the Tax Code of the Russian Federation", noted that the institution of tax optimization has a special value in tax law, as it allows taxpayers to use legal ways to minimize tax payments. Candidate of Law Sciences, Associate Professor, Associate Professor of the Department of International Law of Yanka Kupala State University of Grodno L.Ya. Abramchik (the Republic of Belarus), in the report "Implementation of the principles of tax law in the process of tax administration: axiological aspects" noted that in modern conditions of society, the state development needs to consider societal values. One of the main elements of the effective functioning of the tax system and the economy of the state as a whole is tax administration, so the study of the axiological aspects of applying the principles of tax law in the process of tax administration is relevant and important. Based on the analysis of the system of tax law principles, the speaker justified the conclusion that the state's activities in the field of finance for tax revenue will be effective if there are implemented optimal mechanism of tax administration based on the principles of tax law. Successful tax administration leads to an increase in tax revenues to the budget, reduction of tax offenses, improvement of the investment climate, and ensuring the rights and legitimate interests of participants in tax relations. Professor, doctor of Legal Science, Professor 
of the Department of Financial Law of the University of Wroclaw, P. Zawadzka (the Republic of Poland), speaking on "Legal changes in the field of calculating the debt of local governments in Poland", drew attention to changes in legislation in the field of calculating the debt of local governments. Doctor of Legal Science, Associate Professor, Associate Professor of the Department of Financial Law of the University of Wroclaw K. Kopyściańska (Republic of Poland) in the report "Consolidation of the tax system within the framework of income tax on the example of a controlled foreign company (CFC)" drew attention to the fact that the legal norms of the CFC play an important role in the system of Polish tax law, being an effective mechanism in the fight against tax evasion. However, these legal regulations have some shortcomings that make them one of the most obscure and complex in the entire institution of Polish tax law. Candidate of Law Sciences, Associate Professor of the Department of State and Municipal Law of the F.M. Dostoevsky Omsk State University, K.V. Maslov in the report "Tax security as a legal value" pointed out the value characteristics of tax security from the point of view of law, highlighted the essential characteristics of legal values, identified the signs of security as a legal value, disclosed the axiological properties of tax security and, taking them into account, made recommendations for improving legislation. Candidate of Law Sciences, Associate Professor, Associate Professor of the Department of International Law of the Yanka Kupala State University of Grodno, O.N. Shupitskaya (the Republic of Belarus) in the report "The Constitutional Court of the Republic of Belarus and the axiological assessment of financial legislation" drew attention to the issues of evaluating acts of financial legislation from the point of view of the axiological approach and pointed out that this assessment is given by the Constitutional Court of the Republic of Belarus when it carries out its activities.

During the three thematic blocks of the conference "Axiological aspects of law-making in the financial law of Central and Eastern Europe", "Axiology in Tax Law", "Axiology in budget law, financial law of local government and self-government" - the following speakers were presented: - Dr J. Marczak (University of Lodz, the Republic of Poland) with the report "Institute of Finance: economic determinants of public finance"; - PhD in law, Associate Professor of the Department of Public Finance and Financial Law at the University of Bialystok U. Zawadzka-Pąk (the Republic of Poland) with the report "Value-based Participatory Budgeting in Poland - Successes and Challenges";
- PhD in law, Associate Professor of the Department of Public Finance and Financial Law, University of Bialystok E. Lotko (the Republic of Poland) with the report "The ethical and legal aspects of tax in Poland"; - doctor of Legal Science, Professor, the Head of the Department of Administrative and Financial Law at the Law Faculty of the University of Zielona Góra, A. Gorgol (the Republic of Poland) with the report "Structuring the normative values of tax procedures"; - doctor of Economics, Professor, Head of the Department of Tax Law, Department of State, Municipal Finance and Financial Engineering of the Southern Federal University D.A. Artemenko with the report "The legal support of tax control over the calculation of corporate income tax"; - candidate of Law Sciences E.V. Abbyasova (Center for Unified Expert Service, Saint Petersburg) with the report "Development of financial control in the context of global changes in financial regulation and digitalization of the economy"; - candidate of Law Sciences, Associate Professor, Associate Professor of the Department of Legal Regulation of Economy and Finances at the Institute of Public Administration and Management of the Russian Presidential Academy of National Economy and Public Administration T.A. Nikolaeva with the report "Axiological aspects of constitutional and legal regulation of financial relations"; - candidate of Law Sciences, teacher of the Department of Financial Law, Tax Law and Economics of the Pavol Jozef Šafárik University in Kosice A. Popovich (the Slovak Republic) with the report "Principles and maxims of tax administration, their place in the system of leading values of law and society"; - PhD in law, Associate Professor of the Department of Financial Law and Economics of Masaryk University in Brno D. Šramková (the Czech Republic) with the report "Axiology in tax and customs law"; - PhD in law, Associate Professor of the Department of Financial Law and Economics of the Masaryk University in Brno E. Tomášková (the Czech Republic) with the report "Axioms in budget law on the example of the Czech Republic".

The conference participants were very interested in the reports of young scientists presented during the conference at the section of young scientists. The session was moderated by the Candidate of Law Sciences M. Stoyakova (Pavol Jozef Šafárik University of Kosice, the Slovak Republic). On the meeting were discussed issues related to values in the strategy of customs administration, the right of a tax subject to minimize tax duties, continuity of approaches to analyse financial stability of budget organizations, values in the systems of financial and land law, 
tax doctrine in the system of values of tax law, and other axiological aspects of financial law.

The moderator of the discussion on the main report was a Candidate of Law Sciences, Associate Professor of the Yanka Kupala State University of Grodno L.Ya. Abramchik (the Republic of Belarus). The conference ended with a summary of the results. Modern axiological problems of constitutional, financial, municipal, land and customs law of Belarus, Russia, Poland, the Czech Republic, Slovakia, and Kazakhstan were discussed, as well as ways to resolve them.
In the framework of the conference was organized a meeting of the Center for Information and Research Organization in Public Finance and Tax Law of in the Countries of Central and Eastern Europe, during which were elected governing bodies for a new period and proposed development directions of the Center.

The collection of scientific articles "Axiology in the financial law of Central and Eastern European States" (Grodno, 2019) was published. The decision to conduct a scientific study of the problems raised at the conference and prepare a collective monograph was made. 